\title{
Interaction and the end of the Late Bronze Age as displayed through neutron activation analysis of Late Helladic sherds: a case study on Asine in the Argolid, Greece
}

\author{
B. L. Sjöberg ${ }^{1}$ (D) H. Mommsen ${ }^{2}$
}

Received: 9 September 2020 / Accepted: 28 April 2021 / Published online: 2 July 2021

(C) The Author(s) 2021

\begin{abstract}
This article discusses the results of neutron activation analysis made on a limited number of LH IIIB and LH IIIC period sherds from the Argive settlement Asine, Greece. The analysis indicates that the transformation from the palatial to the post-palatial period, on a local level of a village as Asine, was not signified by loss of contacts with the surrounding world. Rather continuity and interaction prevailed, although with other geographical areas as production and use of pottery in the LH IIIB period apparently had a more regional preponderance. The geographical dominance of pottery assigned to producers in north-eastern Peloponnese and distributed over the Mediterranean was terminated, but other operators may have responded to the demand for pottery.
\end{abstract}

Keywords NAA neutron activation analysis $\cdot$ Asine $\cdot$ Greece $\cdot$ Late Bronze Age $\cdot$ Interaction $\cdot$ Continuity

\section{Introduction}

A major puzzle in Mycenaean studies is the causes and implications of the destruction of settlements and in particular the palaces in about 1200 BC. Following a phase of apparent prosperity during Late Helladic IIIB, the complex administrative system visible during this period is no longer to be seen. Linear B tablets, large-scale storage facilities and other expressions of a centralised political power appear not to have survived. Several studies have tried to come to grips with the nature and consequences of the disaster that struck (Drews 1993; Nur and Cline 2000; Maran 2009; Sjöberg in Weiberg et al. 2010; Drake 2012; Middleton 2012; Knapp and Manning 2016; Lantzas 2016; Finné et al. 2017; Whittaker 2017; Driessen 2018; Weiberg and Finné 2018). Scholars who have devoted attention to this event are not necessarily in agreement, yet it is widely held that the highly organised

B. L. Sjöberg

birgitta.sjoberg.2@gu.se

1 Department of Historical Studies, University of Gothenburg, Gothenburg, Sweden

2 Helmholtz-Institut für Strahlen- und Kernphysik, University of Bonn, Bonn, Germany society visible in the archaeological record during LH IIIB experienced a radical change also in existing socio-economic structures.

Not everything was made subject to such dramatic change, however. An increasingly voluminous literature argues that society beyond the palaces displayed a considerable amount of resilience, opening up for new modes of exchange and less centralised control (Small 1998; Sjöberg 2004; Galaty and Parkinson 2007; Crielaard 2011; Nakassis et al. 2011; Parkinson et al. 2013; Pullen 2013; Shelmerdine 2013). Before long, many settlements were revived or can be seen to have continued to function across this momentous divide. If the polity was heavily centralised, and the economy very dependent on that central power, what were the sources of resilience? Or is it simply an expression of our lack of knowledge about society beyond the palaces? One way of resolving the conflicting information available to us is to think of LH IIIB society and economy as being made up of distinct circles or activities, only some of which were controlled by the palaces (Halstead 1992; Sjöberg 2004). In their shadow, everyday activities continued without much interference from central powers, and, as a result, when the palaces fell on hard times, the rest of society was not as severely affected. Local production and lateral exchange links would then have continued as in the past or were made to fill the gap. As has been shown with respect to pottery production, for instance, there is little 
mention in the Linear B records of the industry or trade in its products (Galaty 1999; Knappett 2001; Whitelaw 2001); hence, as an industry, it can be assumed to have been of a more decentralised character. As such, it may have weathered the crisis better than would otherwise have been the case. Even so, a dominant source of ceramics at least in the Argolid, the one characterised as belonging to the MYBE group, disappears from the archaeological record outside the region as we move from LH IIIB to LH IIIC. Therefore, we need to find a means to assess the changes, if any, that affected production, exchange and use across these two periods also for industries and products that might have operated in a more decentralised mode.

Addressed to the exchange part of the equation, this article aims to analyse the provenance of sherds found in a decentralised context. It does so with a view to investigating continuity or change, approaching the issue of exchange and more indirectly production in a manner partly along the lines suggested by Gilstrap (2014). If it can be shown that intraregional exchange does not change across the divide, it will provide an additional piece of evidence for the resilience of Argive society also as the palaces collapsed. If, on the other hand, there is no evidence for continued exchange, we will have to assess the situation differently. For while the absence of similar ware in LH IIIC as compared to LH IIIB cannot irrevocably be taken as a sign of disruption, it will force us to allow for that possibility, and we will therefore need to devote more effort to establishing the precise state of affairs. In either case, indications of inter-regional exchange (or its absence) serve to put any evidence of intra-Argive movements of pottery in a wider context.

For the purposes of this assessment of provenance and distribution of ceramics as seen from the vantage point of localities away from the palaces and settlements immediately adjacent to them, the paper will focus on Asine. A small settlement at the margins of the Argive plain, it also had the potential to act as an entrepôt for the region. As a research site, it combines the two useful traits of being peripheral and being a potential gateway with the advantage of having been the object of extensive archaeological investigations for about a century. In order to leverage this to the benefit of our understanding of ceramics provenance and exchange, against the background of the important prior contributions made by pottery experts, we build our contribution on a strategic sample of sherds from Asine on which neutron activation analysis is performed.

\section{Asine by the bay: geographical scope of the study}

The Argive Plain, located in the north-eastern part of the Peloponnese, is a coastal plain of about $243 \mathrm{~km}^{2}$, surrounded by hills and low mountains rising to $400-700 \mathrm{~m}$ above sea level. After the polar caps started to melt, the coastline shifted position and at the east side of the Argive plain Tiryns came closer to the coast (Zangger 1991). The final deposit affecting the area seems to have taken place in the LH IIIB2 or early LH IIIC period caused by diversion of a stream close to Tiryns (Zangger 1994). The settlement of Asine is located in the south-eastern 'appendix' of this geographically well-defined plain. The location of the village on the coast will be of importance in evaluating the status of the site in a regional settlement system as proximity to water, and harbour facilities, give a settlement a natural advantage in extra-regional exchange.

\section{Sample choice}

The sherds in the analysis are all from the Lower Town of Asine, excavated by O. Frödin and A.W. Persson in 1926 and published in 1938. The publication is rewarding in many ways, but there are also some problems, notably the stratigraphy, information on which is at times conflicting (e.g. excavated material does not always match excavation records). A later re-examination of the houses located in the Lower Town has established a clear dominance for LH IIIC remains. This is in contrast to evidence from the LH IIIA/B period, which is fragmentary; layers older than LH IIIC were not systematically pursued (Sjöberg 2004). That said, there are other areas attesting to LH IIIA/B habitation in the area of Asine, including the Barbouna Area as well as the nearby village of Zafer Aga (Frizell 1978; Santillo Frizell 1980; Sjöberg 1996). Also the chamber tombs add to our knowledge on the extent to which there is continuous habitation (Mountjoy 1996; Sjöberg 2004). Although no larger and more detailed study on assemblage composition has been made on the material from the Lower Town, we may note that similar to the Barbouna area (Santillo Frizell 1980), Lower Town pottery display a combination of decorated tableware, storage vessels and coarse ware.

The archaeological material from the old excavations, stored in the Historic Collections of Gustavianum, Uppsala University Museum, Sweden, consists mainly of sherds kept in approximately 5000 boxes. The finds and documentation from Asine are now available in the online database PRAGMATA (Nordquist and Lindblom 2020). The pottery excavated in the Lower Town was cleaned and 'usually washed in nitric acid' (Nordquist and Hägg 1996, 14). Combined with a lack of whole shapes and even good profiles, this makes identification and dating problematic (Santillo Frizell 1980; Sjöberg 2004). The boxes usually provide information on the excavation date, find context and sometimes depth of the layer. However, since the find context only refers 
to rather broad areas, it is not always easy to collate with excavation map and field diaries (Sjöberg 1997, 2004; Lindblom et al. 2018).

A total of ten samples from the excavations in the Lower Town conducted in 1926 are analysed here. Visual inspection assessing decoration and fabric was used to select five sherds from each period, LH IIIB and LH IIIC (Figs. 1 and 2, Table 1). As mentioned, material from LH IIIB is infrequent in the predominantly LH IIIC context of the Lower Town, and material from the earlier period is spread out in boxes dominated by LH IIIC material. As the prime focus was the sherds themselves rather than the detailed specificities of the intra-site find context, this is not a major drawback.
The sherds are described (Table 1), when applicable, by using FM and FS, the classifications assigned to Furumark (1941).

\section{The neutron activation analysis (NAA) procedure and archaeometric results}

The samples have been analysed by NAA in the Bonn archaeometry laboratory that uses this method since about 30 years. The resulting weight elemental concentration patterns comprise 30 minor and trace elements, if present above the detection limit, measured often with uncertainties of only a few percent. This pattern or elemental profile characterises the

Fig. 1 LH IIIB sherds Asin 2125. Photo: B.L. Sjöberg

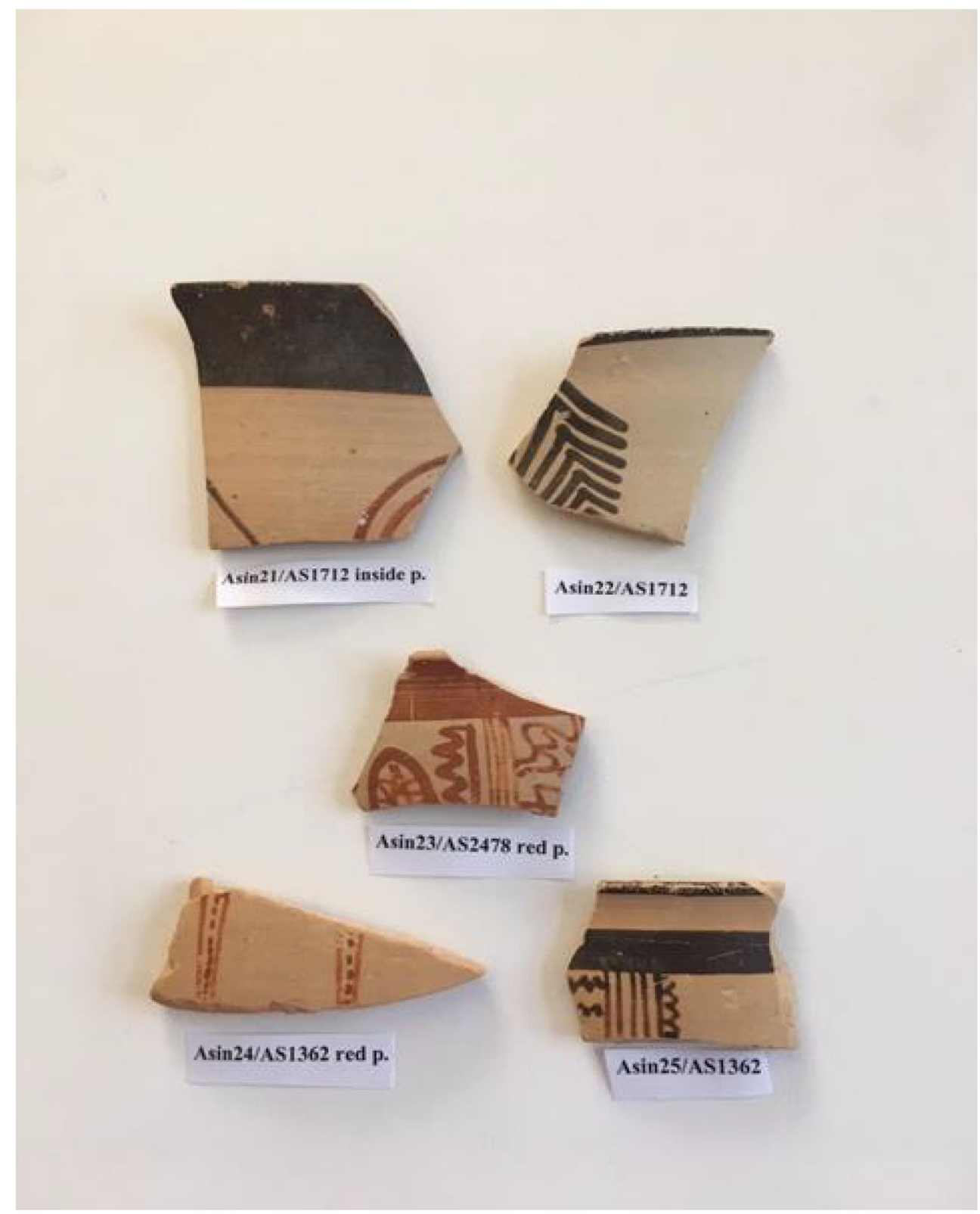


Fig. 2 LH IIIC sherds Asin 2630. Photo: B.L. Sjöberg

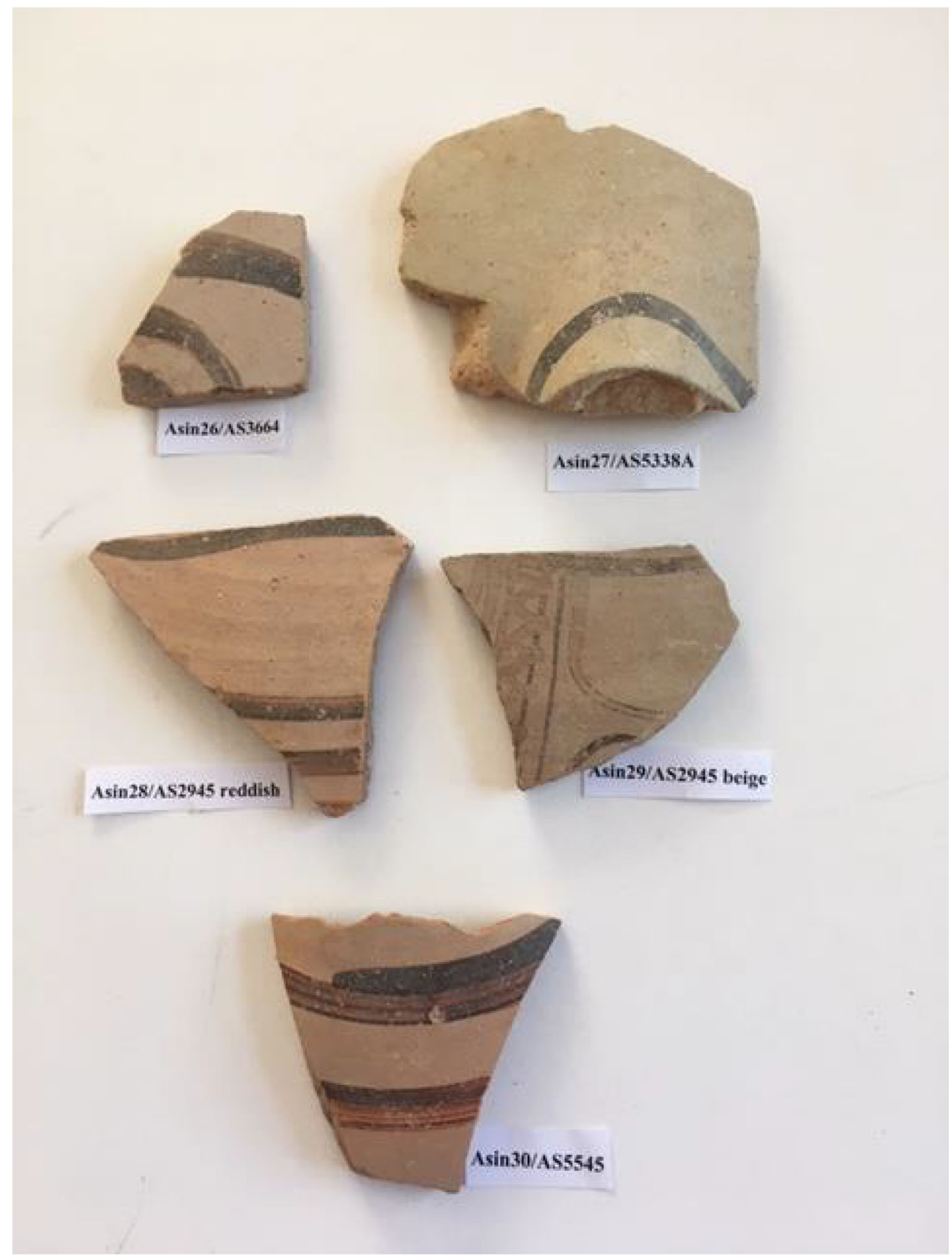

composition of the clay paste used by the ancient potters to produce their wares. It can be assumed to have a high probability to be different for pottery workshops at different locations or regions, even different for different paste recipes in a single workshop. Pottery vessels or sherds having the same composition inside small uncertainty bars, therefore, can be assumed to have the same origin. This origin and therefore provenance of single vessels is established, if its elemental profile is similar to profiles known from measurements of so-called reference material of this origin. The NAA procedure in Bonn has been described several times (Mommsen et al. 1991; Mommsen 2011; Gilboa et al. 2017 and references therein). The important parameters are summarised here: pottery sample size $80 \mathrm{mg}$, irradiations at the Research Reactor Geesthacht, Germany, at a flux of about $5 \times 10^{13}$ neutrons per $\mathrm{cm}^{2}$ and $\mathrm{s}$ during $3 \mathrm{~h} ; 4$ measurements at different time intervals after the irradiation, Bonn NAA pottery standard (composition given in Mommsen and Sjöberg 2007) calibrated with the Berkeley pottery standard (Perlman and Asaro 1969). The comparison of the obtained elemental profiles is done with a statistical filter procedure developed in Bonn (Mommsen et al. 1988a; Beier and Mommsen 1994). Out of a large databank all samples statistically similar to a given elemental composition can be filtered out to form a group of 
Table 1 List of samples analysed and discussed in the paper

\begin{tabular}{|c|c|c|c|c|c|}
\hline $\begin{array}{l}\text { Asine } \\
\text { inventory } \\
\text { number }\end{array}$ & $\begin{array}{l}\text { NAA } \\
\text { sample } \\
\text { number }\end{array}$ & Type & Context & Remark & NAA \\
\hline \multicolumn{6}{|l|}{ LH IIIB } \\
\hline AS1712 & $A \sin 21$ & $\begin{array}{l}\text { FS } 284 \text { deep bowl } \\
\text { FM } 46 \text { running spiral }\end{array}$ & $\begin{array}{l}\text { Area: Lower Town, Mycenaean Palace- Upper } \\
\text { Mycenaean house, antae }\end{array}$ & $\begin{array}{l}\text { Frizell 1978, figs. 47, 48. 32. LH IIIB } \\
\text { Santillo Frizell 1986, fig. 26. 235a } \\
\text { French and Stockhammer 2009, } \\
\text { fig.14.1. LH IIIB2 }\end{array}$ & TheB \\
\hline AS1712 & $A \sin 22$ & $\begin{array}{l}\text { FS } 284 \text { deep bowl } \\
\text { FM } 58 \text { chevron }\end{array}$ & $\begin{array}{l}\text { Area: Lower Town, Mycenaean Palace- Upper } \\
\text { Mycenaean house, antae }\end{array}$ & $\begin{array}{l}\text { Frizell 1978, figs. } 65 b ; 66.107 \text {, LH IIIB. } \\
\text { French and Stockhammer 2009, figs. } \\
\text { 4.1; } 13.8 \text {. } \\
\text { LH IIIB2 }\end{array}$ & MYBE \\
\hline AS2478 & $A \sin 23$ & $\begin{array}{l}\text { FS } 284 \text { deep bowl } \\
\text { FM } 75 \text { panel with arrow fringe }\end{array}$ & Area: Lower Town. Trench: House N & Mountjoy 1986, fig. 143.10. LH IIIB1 & MYBE \\
\hline AS 1362 & $A \sin 24$ & $\begin{array}{l}\text { FS } 9 \text { krater? } \\
\text { FM } 23 \text { whoorl-shell }\end{array}$ & $\begin{array}{l}\text { Area: Lower Town, Mycenaean Palace-West of } \\
\text { the palace. South room }\end{array}$ & $\begin{array}{l}\text { Frizell 1978, figs. 57. } 64 ; 59 \\
\text { Mountjoy } 1986 \text {, figs. } 135 ; 156\end{array}$ & Single \\
\hline AS1362 & $A \sin 25$ & $\begin{array}{l}\text { FS } 284 \text { deep bowl, FS } 305 \\
\text { stemmed bowl? FM } 75 \\
\text { panel with joining } \\
\text { semi-circle fringe }\end{array}$ & $\begin{array}{l}\text { Area: Lower Town, Mycenaean Palace-West of } \\
\text { the palace. South room }\end{array}$ & $\begin{array}{l}\text { Santillo Frizell 1986, fig. 26. 234. LH } \\
\text { IIIB (krater or big deep bowl) } \\
\text { Mountjoy 1986, figs. 161.9; 165. LH } \\
\text { IIIB2. French and Stockhammer } \\
\text { 2009, figs. 6. 3;12. 1; 19. 3. LH } \\
\text { IIIB2 }\end{array}$ & MYBE \\
\hline \multicolumn{6}{|c|}{ 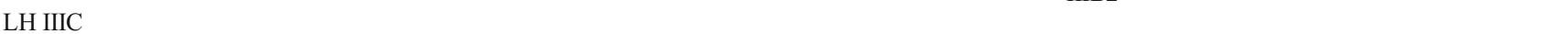 } \\
\hline AS3664 & $A \sin 26$ & $\begin{array}{l}\text { FS? FM } 46 \text { appears in LH IIIC } \\
\text { on FS } 284 \text { deep bowl, } \\
\text { kraters, FS } 63 \text { collar-necked } \\
\text { jar }\end{array}$ & $\begin{array}{l}\text { Area: Lower Town, Lower Section, Myc. Palace, } \\
\text { immediately above palace floor }\end{array}$ & $\begin{array}{l}\text { Mountjoy } 1986 \\
\text { LH IIIC }\end{array}$ & $\operatorname{Tan} \mathrm{A}$ \\
\hline AS5338A & $A \sin 27$ & $\begin{array}{l}\text { Handle-body with splash } \\
\text { round stub. FS63 } \\
\text { collar-necked jar, FS69 } \\
\text { amphora or FS128 hydria? }\end{array}$ & $\begin{array}{l}\text { Area: Lower Town, Mixed-Two contexts: } 1 \text {. } \\
\text { Upper Mycenaean house, } 240-260,26 / 6-26 \text {; } \\
\text { 2. North-west of upper Mycenaean house, } \\
\text { 220-240, 23/6-26 }\end{array}$ & $\begin{array}{l}\text { Santillo Frizell } 1986, \text { no. } 410 \\
\text { Mountjoy } 1986 \\
\text { Figs. } 171 ; 178 \\
\text { LH IIIC or Transitional? }\end{array}$ & AEGE \\
\hline AS2945 & $A \sin 28$ & $\begin{array}{l}\text { FS } 282 \text { krater? } \\
\text { FM53, a broad wavy line? } \\
\text { Body banded }\end{array}$ & $\begin{array}{l}\text { Area: Lower Town, Lower Section, Mycenaean } \\
\text { palace, above the floor }\end{array}$ & $\begin{array}{l}\text { Mountjoy } 1986 . \\
\text { LH IIIC: M/L? }\end{array}$ & KnoL/TheB \\
\hline AS2945 & $A \sin 29$ & $\begin{array}{l}\text { FS } 284 \text { deep bowl? } \\
\text { FM50 antithetical spirals, } \\
\text { panel framed by zigzag }\end{array}$ & $\begin{array}{l}\text { Area: Lower Town, Lower Section, Mycenaean } \\
\text { palace, above the floor }\end{array}$ & $\begin{array}{l}\text { Santillo Frizell 1986, fig. } 16.119 \text { panel } \\
\quad \text { zigzag, p. 76, LH IIIC } \\
\text { Mountjoy 1986, fig. 189. 2. LH IIIC:E }\end{array}$ & ChiA \\
\hline AS5545 & $A \sin 30$ & $\begin{array}{l}\text { FS? } \\
\text { FM? Body banded }\end{array}$ & Area: Lower Town, East-Lower part & LH IIIC & U126 \\
\hline
\end{tabular}

samples of the same origin. During the filter process the experimental uncertainties of single samples or the standard deviations of already existing groups are considered and also possible dilutions or elutriations of the clay paste are corrected by a best relative fit factor. These features cannot be included in the often used principal component analysis or the different cluster analyses producing dendrograms (Baxter 2003).

Comparing the Bonn databank of known pottery profiles, several of the 10 samples could statistically be matched to already formed groups as indicated in Tables 2 and 3. Three of the five samples from the LH IIIB period (Asin 22, 23, 25) have the composition MYBE that is very common in all sample sets from sites in the Argolid. It was seen already during the first measurements of the laboratory in Bonn in samples from Mycenae and Tiryns (Mommsen et al. 1988b, called there $\mathrm{MB}$ ) and ascertained by already existing NAA measurements of the Lawrence Berkeley National Laboratory (LBNL) (Karageorghis et al. 1972). Wasters from the Berbati workshop(s) with this same profile assigned all members of the group MYBE to an origin of this site. But the Berbati pottery workshop itself is known to have been probably not in use after LH IIIA1, however although no additional kiln is found wasters from LH IIIA2/LH IIIB periods suggest that production continued (Åkerström 1987; Schallin 1997, 2015; Klintberg 2011). In addition, more recent NAA studies have demonstrated that this pattern must represent a general profile both geographically and chronologically assigned to also other regions and production centres than Berbati (Zuckerman et al. 2010; Mommsen 2012). For example, pieces with the MYBE profile are found in a set of samples from Corinth of the classical period (Mommsen et al. 2016). As long as no other reference material with this profile at a given site is analysed, we prefer to indicate the entire northeastern Peloponnese as origin for the profile MYBE.

One vessel Asin 21 from the period LH IIIB has the pattern TheB assigned to workshops at Thebes in Boeotia (Mommsen 
Table 2 Asine, 5 vessels of the time period LH IIIB

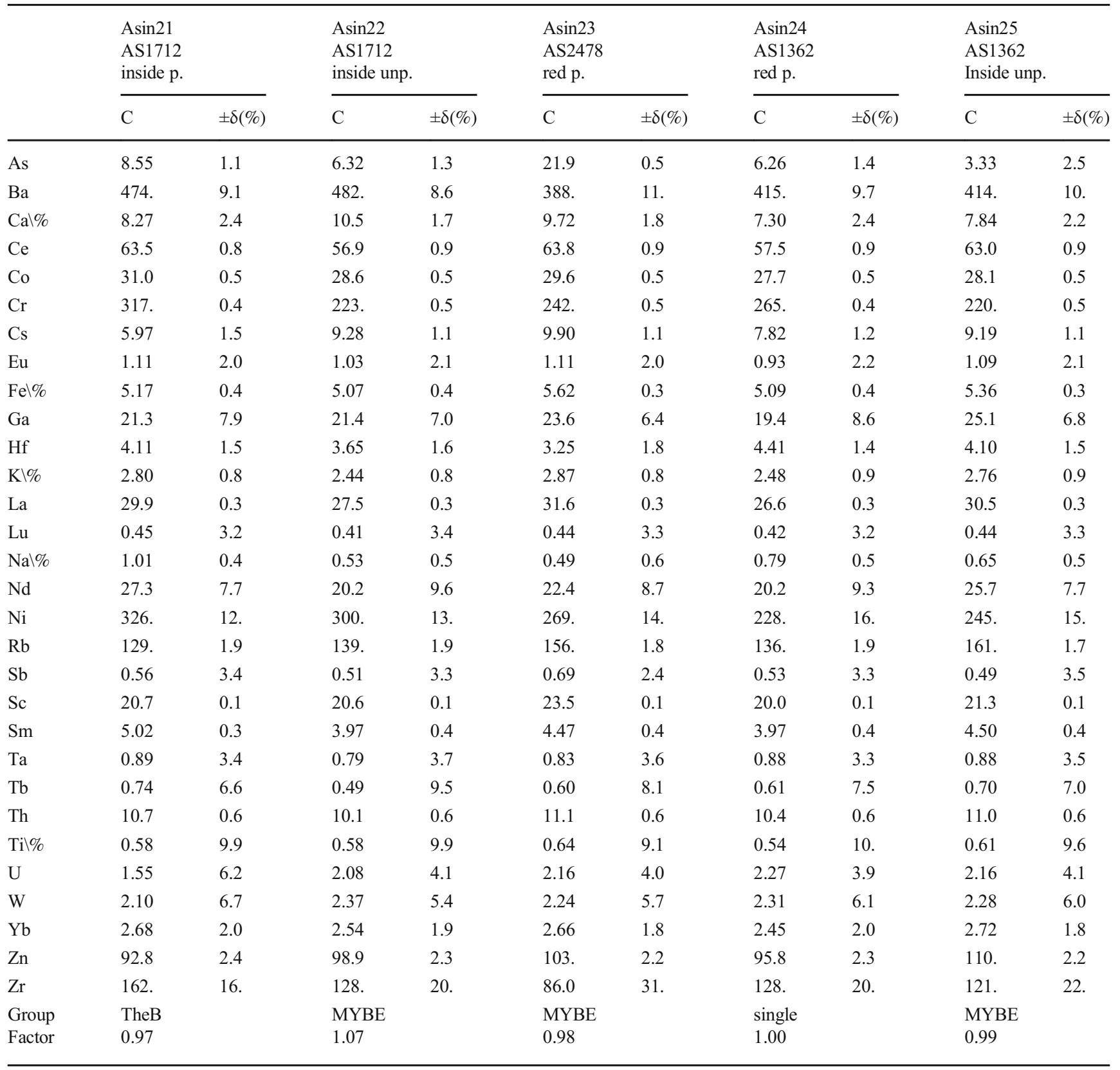

Concentrations $\mathrm{C}$ of elements in $\mu \mathrm{g} / \mathrm{g}(\mathrm{ppm})$, if not indicated otherwise, and experimental uncertainties (error) $\delta$ in $\%$ of C. The sample is member of the group given below the elemental values together with its individual best relative fit factor with respect to this group. Single means chemical loner

and Maran 2000-2001; Schwedt et al. 2006 [group B = TheB]). The match to a very similar pattern KnoL assigned to Central Crete can be excluded here because of amongst others mainly the $\mathrm{Rb}$ value of $(129 \pm 1.9) \mathrm{ppm}$ that is higher for Boeotia than for Central Crete Rb: $(106 \pm 7.1)$ ppm (Gilboa et al. 2017). The sample Asin 24 has a chemical composition that is new to us and a single in our databank of now more than 12600 samples from the Central and Eastern Mediterranean. It might represent the first sample of a still unknown pottery workshop or been contaminated in antiquity or in our times.
The picture is different for the time period LH IIIC. None of the 5 samples has the concentration pattern MYBE. Sample Asin 26 has the Boeotian pattern TanA assigned by a clay sample to a workshop(s) at or near Tanagra (Mühlenbruch and Mommsen 2011). A second sample Asin 28 has a composition that archaeometrically has to be assigned with nearly similar probabilities to Boeotia (group TheB despite the low Rb value) and Central Crete (group KnoL, Gilboa et al. 2017). Sample Asin 27 has also a pattern AEGE already known and indicating with high probability an origin from Aegina 
(Mommsen et al. 2001). Asin 29 is according to its concentration pattern an import from Chios (Demakopoulou et al. 2017; Lis et al. 2020; Huy et al. 2020). With lower probability, an origin in Attica is possible, nevertheless with deviating lower $\mathrm{Rb}$ and $\mathrm{K}$. The last sample Asin 30 has a profile U126, with 15 members in the Bonn databank that is still not located with certainty (Forsén et al. 2017).

\section{Discussion}

\section{The LH IIIB period}

As has been noted above, the MYBE concentration profile was not delimited to the workshop(s) of Berbati only but points very probably to a number of different workshops in the region of the north-eastern Peloponnese so far not identified. A larger number of Late Helladic sherds from Midea have this profile; according to Demakopoulou et al. (2017), the pottery was produced in specialised workshops intended for the great Argive centres but also for export. Although set in another regional context, the kingdom of Pylos, in an early study, Whitelaw (2001) demonstrated the decentralisation of pottery production with limited palatial involvement. As was pointed out by Whitelaw, in any attempt to extrapolate the Pylos model to other regions, caution should be exercised, but the results of the investigation are of interest for how we might understand the construction of regional economies in the wider Late Helladic society. With an improved knowledge concerning production and distribution of Argive pottery, the importance of adopting a regional lens for assessing the nature of the economy should not be neglected.

As concerns Asine specifically (see Maps 1 and 2), the samples do not contradict observations to the effect that regionalism in production and exchange may be at hand. This is so as three samples in this case study (Asin 22, 23, 25) show the wellknown pattern MYBE, as expected in a LH IIIB Argive context. These samples and the sample Asin 21, originating in the Boeotian source TheB, point to Asine either taking part in an inter-regional exchange system based on demand at the regional/local level or possibly, thanks to the favourable location on the coast, operating as a gateway for pottery distributed to and from the Argive region or both. While we are in no position to discriminate between these potential explanations, it shows that Asine took part in a wider system of exchange.

That the system did at times extend beyond the shores of the Argolid is not in doubt. The issue here is rather when, in what period or periods. As recently pointed out by Jung et al. (2015), the mass export of fine Mycenaean pottery has long been observed in the material from eastern part of the Mediterranean. There typological features have demonstrated a production directed towards local consumers across the sea. At Tell Kazel, for example, a broad spectrum of types showed to be Mycenaean imports. As demonstrated by macroscopic examination and later confirmed by NAA analysis, the majority had an Argive origin (Jung 2018). The corpus of pottery material on export from the Greek mainland and specifically the Argolid has indeed expanded with the NAA method. Thus, pottery found in some tombs at Laish/Dan was imported from the Argolid (Gunneweg and Michel 1999). This study has since been followed by several others, including analyses of material from Tell el-Safi/Gath Israel (Mountjoy and Mommsen 2001; Ben-Shlomo et al. 2008). Results from an analysis of pottery from Northern Israel, based on NAA, list 138 samples out of 183 vessels as sharing the MYBE profile. That study also identifies the complexity in trade patterns with intra-regional distribution of imported pottery of the clay profile MYBE with Tell Abu Hawam acting as the main gateway for the region (Zuckerman et al. 2010). The geographical extent of trade and the complexity of the operations are also demonstrated in a sample from Tarsus-Gözlükule, Turkey, as NAA assigns it to the north-east Peloponnesian group, MYBE (Mommsen et al. 2011). Similarly, in a recent study by Spataro et al. (2019), Mycenaean pottery found at Amara West (Nubia, Sudan) is attributed to the MYBE group.

Combined, these recent studies give a hint of the magnitude of trade contacts during the Late Bronze Age IIIB, and, critically, they help position the Argive economy as a partner in long-distance trade with external markets. It also suggests that the palatial period in the Argolid may not have been dependent on one major palatial site (i.e. Mycenae), for the distribution of goods. Instead, thanks to geographical location or infrastructure, several sites may have functioned as nodes for commercial activity. Due to its position as a centre but also with a port as favourable located close to the coast, Tiryns is likely to have been an important node for maritime contacts (Maran 2009; Stockhammer 2011; Kardamaki et al. 2016). Yet there is nothing to suggest that Tiryns, to the extent it served as the transhipment point at all, was alone and Asine could be one of the alternatives available. It is simply not possible to tell. What the samples analysed do demonstrate is that Asine participated in an intra-Argive exchange, possibly both as a local consumer of the regionally produced highquality pottery and conceivably also as a node for extraregional distribution of regional and non-regional products.

Hypothesising for the region of Argolid such a decentralised pattern of pottery production and exchange, as demonstrated by finds of sherds of the MYBE provenance, is consonant with research that suggests that the view of the Late Helladic society as being under total palatial control needs to be revised (Small 1998; Sjöberg 2004; Galaty and Parkinson 2007; Crielaard 2011; Nakassis et al. 2011; Parkinson et al. 2013; Pullen 2013; Shelmerdine 2013). Yet it does not in itself tell us if this state of affairs also pertained to the period following the collapse of the palaces. 
Table 3 Asine, 5 vessels of the time period LH IIIC

\begin{tabular}{|c|c|c|c|c|c|c|c|c|c|c|}
\hline \multirow{2}{*}{ 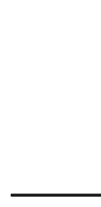 } & \multicolumn{2}{|c|}{$\begin{array}{l}\text { Asin26 } \\
\text { AS3664 } \\
\text { thick }\end{array}$} & \multicolumn{2}{|c|}{$\begin{array}{l}\text { Asin27 } \\
\text { AS5338A } \\
\text { with handle }\end{array}$} & \multicolumn{2}{|c|}{$\begin{array}{l}\text { Asin28 } \\
\text { AS2945 } \\
\text { reddish }\end{array}$} & \multicolumn{2}{|c|}{$\begin{array}{l}\text { Asin29 } \\
\text { AS2945 } \\
\text { beige }\end{array}$} & \multicolumn{2}{|c|}{$\begin{array}{l}\text { Asin30 } \\
\text { AS5545 }\end{array}$} \\
\hline & $\mathrm{C}$ & $\pm \delta(\%)$ & $\mathrm{C}$ & $\pm \delta(\%)$ & $\mathrm{C}$ & $\pm \delta(\%)$ & $\mathrm{C}$ & $\pm \delta(\%)$ & $\mathrm{C}$ & $\pm \delta(\%)$ \\
\hline As & 9.86 & 1.1 & 9.69 & 1.0 & 11.7 & 1.0 & 32.3 & 0.4 & 9.37 & 1.2 \\
\hline $\mathrm{Ba}$ & 418. & 11. & 521. & 8.1 & 484. & 9.0 & 381. & 11. & 413. & 10. \\
\hline $\mathrm{Ca} \mid \%$ & 8.22 & 2.7 & 9.79 & 2.0 & 7.91 & 2.6 & 8.65 & 2.2 & 5.76 & 3.2 \\
\hline $\mathrm{Ce}$ & 59.4 & 0.9 & 55.1 & 0.9 & 59.9 & 0.9 & 63.5 & 0.9 & 64.3 & 0.8 \\
\hline Co & 36.7 & 0.5 & 18.6 & 0.6 & 34.5 & 0.5 & 36.1 & 0.5 & 29.9 & 0.5 \\
\hline $\mathrm{Cr}$ & 596. & 0.4 & 386. & 0.4 & 522. & 0.4 & 478. & 0.4 & 390. & 0.4 \\
\hline Cs & 4.84 & 1.8 & 7.01 & 1.3 & 5.46 & 1.6 & 11.3 & 1.0 & 5.40 & 1.6 \\
\hline $\mathrm{Eu}$ & 1.10 & 2.0 & 1.03 & 2.1 & 1.03 & 2.1 & 1.17 & 2.0 & 1.13 & 2.0 \\
\hline $\mathrm{Fe} \backslash \%$ & 5.00 & 0.4 & 4.46 & 0.4 & 5.28 & 0.3 & 5.24 & 0.4 & 4.90 & 0.4 \\
\hline $\mathrm{Ga}$ & 17.9 & 13. & 20.0 & 10. & 25.1 & 9.2 & 20.6 & 11. & 18.0 & 13. \\
\hline $\mathrm{Hf}$ & 4.03 & 1.5 & 4.98 & 1.2 & 3.83 & 1.6 & 4.54 & 1.4 & 4.62 & 1.4 \\
\hline $\mathrm{K} \backslash \%$ & 1.76 & 1.6 & 1.88 & 1.3 & 1.44 & 1.8 & 1.76 & 1.5 & 2.66 & 1.1 \\
\hline $\mathrm{La}$ & 27.7 & 0.3 & 26.0 & 0.3 & 27.8 & 0.3 & 28.1 & 0.3 & 29.8 & 0.3 \\
\hline $\mathrm{Lu}$ & 0.40 & 3.5 & 0.36 & 3.7 & 0.40 & 3.6 & 0.47 & 3.2 & 0.41 & 3.6 \\
\hline $\mathrm{Na} \mid \%$ & 1.77 & 0.4 & 1.11 & 0.4 & 1.44 & 0.4 & 1.04 & 0.5 & 1.17 & 0.5 \\
\hline $\mathrm{Nd}$ & 24.2 & 8.7 & 19.1 & 10. & 24.5 & 8.4 & 27.1 & 7.7 & 24.8 & 8.2 \\
\hline $\mathrm{Ni}$ & 460. & 8.6 & 280. & 13. & 391. & 10. & 413. & 9.8 & 364. & 10. \\
\hline $\mathrm{Rb}$ & 86.3 & 2.5 & 93.2 & 2.3 & 103. & 2.3 & 89.8 & 2.5 & 115. & 2.1 \\
\hline $\mathrm{Sb}$ & 0.63 & 3.3 & 0.67 & 2.7 & 0.57 & 3.5 & 1.32 & 1.6 & 0.56 & 3.4 \\
\hline $\mathrm{Sc}$ & 19.1 & 0.1 & 17.4 & 0.1 & 20.7 & 0.1 & 22.4 & 0.1 & 19.5 & 0.1 \\
\hline $\mathrm{Sm}$ & 4.72 & 0.4 & 4.36 & 0.4 & 4.68 & 0.4 & 5.13 & 0.4 & 4.76 & 0.4 \\
\hline $\mathrm{Ta}$ & 0.82 & 3.6 & 0.82 & 3.5 & 0.89 & 3.5 & 0.89 & 3.5 & 0.91 & 3.3 \\
\hline $\mathrm{Tb}$ & 0.62 & 7.4 & 0.61 & 7.2 & 0.62 & 7.7 & 0.64 & 7.7 & 0.67 & 7.2 \\
\hline Th & 9.75 & 0.6 & 9.28 & 0.6 & 10.4 & 0.6 & 10.1 & 0.6 & 10.4 & 0.6 \\
\hline Ti\\
% & 0.69 & 9.0 & 0.46 & 13. & 0.48 & 13. & 0.62 & 10. & 0.40 & 15. \\
\hline U & 1.64 & 6.5 & 1.85 & 5.0 & 1.72 & 6.0 & 2.18 & 4.4 & 1.74 & 5.6 \\
\hline W & 1.90 & 9.0 & 1.57 & 9.5 & 2.13 & 8.0 & 2.01 & 8.0 & 2.49 & 6.8 \\
\hline $\mathrm{Yb}$ & 2.60 & 2.3 & 2.35 & 2.1 & 2.43 & 2.3 & 2.94 & 1.8 & 2.69 & 1.9 \\
\hline $\mathrm{Zn}$ & 99.3 & 2.3 & 89.7 & 2.3 & 95.4 & 2.4 & 125. & 2.0 & 176. & 1.6 \\
\hline $\mathrm{Zr}$ & 120. & 21. & 148. & 16. & 111. & 23. & 159. & 17. & 139. & 18. \\
\hline Group & TanA & & AEGE & & KnoI & & ChiA & & U126 & \\
\hline Factor & 0.86 & & 0.91 & & $0.97 /$ & & 0.80 & & 0.90 & \\
\hline
\end{tabular}

Concentrations $\mathrm{C}$ of elements in $\mu \mathrm{g} / \mathrm{g}(\mathrm{ppm})$, if not indicated otherwise, and experimental uncertainties (error) $\delta$ in $\%$ of $\mathrm{C}$. The sample is member of the group given below the elemental values together with its individual best relative fit factor with respect to this group. A membership of the 2 nd group shown is statistically possible but with lower probability

\section{The LH IIIC period}

One of the samples conforms to a pattern named U126 (Unlocated group no. 26). The pattern has 15 members in the Bonn databank, mostly unpublished, found in diverse chronological and geographical settings; besides the sample here (Asin 30), it is found, for instance, in 6 other pieces of Aeginetan Ware from Asine dated to the periods EH III to LH IA, in 2 pieces from Tiryns, 2 from Katsingri
(Profitis Ilias), 1 from Lerna and also 1 from Aegina itself. The only published sample is from an Early Helladic sherd collection from Asea, Arcadia. On typological grounds, it is assigned to the so-called Talioti phase, named after the valley Talioti located between Asine and Nauplion (Forsén et al. 2017).

The remaining LH IIIC samples diverge as well from the LH IIIB examples as there is no secured regional ware characterised by the MYBE pattern during this period at 


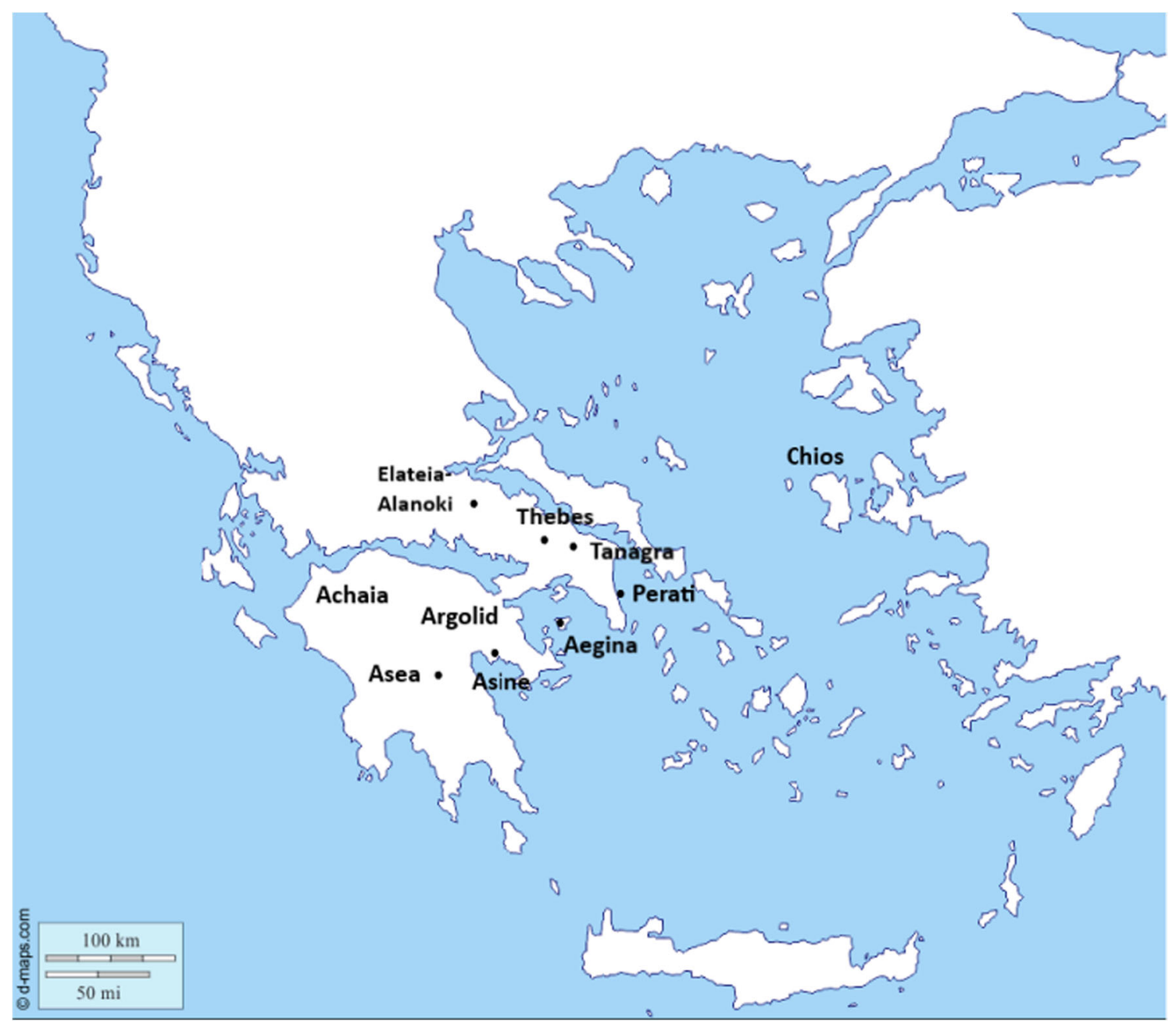

Map 1 The Aegean region. Base map: d-maps, URL https://d-maps.com/carte.php?num_car=3170\&lang=en

Asine. This is in contrast to sherds of the regional pattern MYBE validated in LH IIIC samples from Midea and Tiryns (Mommsen et al. 1988b; Mommsen and Maran 2000-2001; Demakopoulou et al. 2017). As mentioned earlier, it has until rather recently been assumed that there was one single source for the MYBE production, one probably not in use after LH IIIA/B. However, recent NAA studies have demonstrated that the pattern may represent a general profile both geographically and chronologically assigned to more regions and production centres (Zuckerman et al. 2010). Given the small sample examined the lack of an Argive regional pattern may of course be pure coincidence in the Asine case.

The samples include TanA (Tanagra, Boeotia) a pattern demonstrated in a LH IIIC sample, a skyphos, from Sirkeli, Turkey (Mühlenbruch and Mommsen 2011). Another sample $\mathrm{KnoL} / \mathrm{TheB}$ (Thebes) is also a clay paste used in Boeotia. Interestingly, the pattern $\mathrm{TheB} / \mathrm{KnoL}$ is identified in two $\mathrm{LH}$ IIIC samples from Punta di Zambrone in Calabria, Italy (Jung et al. 2015). Asin 27, with the composition AEGE, is most probably from Aegina. As concerns the production of the well-known cooking pottery, this continued for long, and these vessels were traded as late as the LH IIIC early period (Gauss et al. 2017; Lis et al. 2020). Although we still have limited knowledge about production centres, it is worthy of note that the examination of pottery has indirectly demonstrated contrasting practises of manufacturing with also table ware exchanged in the transitional LH IIIB-LH IIIC early period (Gilstrap 2014, 2016). The sample from Asine is perhaps one of those vessels distributed outside Aegina in this transitional period; also the mixed Mycenaean context could be of relevance for dating. The vessel, a jug or hydria, may have been produced in the earlier part of the transitional period and still used in the LH IIIC context of the Lower Town. Stockhammer (2009) has explained reintegration of earlier pottery material in the settlement context of LH IIIC in the Lower Town at Tiryns, as connected to the social positioning of an elite family. Also Maran (2015) has recently adopted this model of palatial relicts in the LH IIIC context operating as former symbols of power directly linking the past with the LH IIIC society. Similarly, Jung et al. (2015) has observed the phenomenon at many Levantine settlements, and not only in religious contexts, with Mycenaean vessels treated with care and 


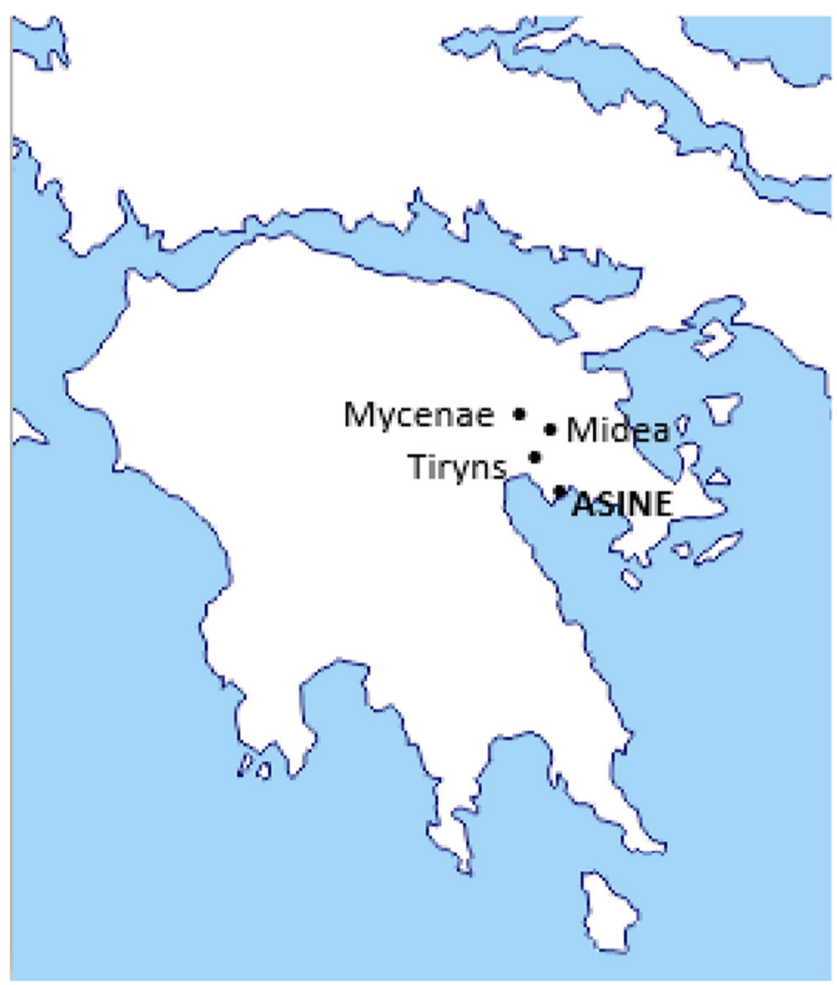

Map 2 The Argolid. Base map: d-maps, URL https://d-maps.com/carte. php?num_car=3170\&lang=en

in use for long. The sample Asin 29 with pattern ChiA is assigned to the island of Chios (Lis et al. 2020; Huy et al. 2020). This particular pattern has also been found elsewhere in the Argolid, namely, in a LH IIIB2 floor deposit at Midea in the form of a transport stirrup jar (Demakopoulou et al. 2017). As a parallel to MYBE and AEGE, in both LH IIIB and LH IIIC periods, ChiA may possibly be understood as an instance where the island of Chios for a long period supplied a wider geographical area with pottery. The pattern ChiA has also been identified in two samples of LH IIIC material from the chamber tombs at Perati (Lis et al. 2020).

In sum, the Asine samples illustrate the existence of extensive geographical networks also in the LH IIIC period. This is in line with existing research. It has been suggested for Achaia (Arena 2015) that due to the presence of imported goods in the LH IIIC period, the region probably benefited from the collapse in the end of LH IIIB. As argued by Demakopoulou (2007a, b), the period LH IIIC Middle saw a flourishing in most regions of the Aegean. An interesting settlement is Elateia-Alanoki in Central Greece as according to S. DegerJalkotzy (2007) imported vases indicate the geographical range of the external contacts during LH IIIC Middle and Late periods. Against this background, it is worthy of note that the reported abandonment of the cemetery at ElateiaAlanoki in the LH IIIC Early was followed by an increase in use in the subsequent phases. The same pattern of reuse of tombs and dominance of LH IIIC Middle and Late vases has also been found at Asine (Mountjoy 1996; Sjöberg 2004).
A survey of the settlement has demonstrated that the time of expansion of Asine covers the middle and late phases of the LH IIIC period; this can be seen in Houses G, H, I and K located in the Lower Town (Sjöberg 2004). As described by the excavators (Frödin and Persson 1938) and reported in field diaries, Houses $\mathrm{H}$ and I both had kilns; there are also some photos of the collapsed constructions. The kiln in House $\mathrm{H}$ is described as a potter's kiln of ordinary type, and burnt clay pieces and sherds exposed to high temperature were found in the corresponding boxes. However, analyses have not been made of the material, so firing temperatures are not confirmed. House I is reported to have a more complex construction, but unfortunately no related finds have been found. The extent to which the two possible kilns may have had importance for the household as a supplement to other sources of subsistence can therefore not be established (Sjöberg 1997). Indeed, the LH IIIC kilns set in a house context should not be compared with the earlier larger units in use, such as that at Kolonna, Aegina, that probably was intended for production of greater quantities of pottery (Karkanas 2019). Further, as concern Asine, the accumulation of LH IIIC material in the Acropolis area demonstrates the extension of the settlement (Santillo Frizell 1986; Penttinen 1996).

Another case relatively close by is that of Tiryns, where the palatial architecture was replaced by a village-like occupation with houses arranged around courtyards and with an extensive settled area and a post-palatial culture (Maran 2002-2003, 2006, 2009; Maran and Papadimitriou 2006, 2016; Mühlenbruch 2007; Stockhammer 2011). According to Stockhammer $(2011,209)$, Tiryns 'became the new paramount representative center', this later flourishing of the settlement being 'the result of the earthquake of $1250 \mathrm{BCE}$ '. Also here a probable LH IIIC kiln has been reported (Kilian 1981, 1982; Rahmtorf 2015). Maran (2005, 2009) observed the presence of foreign objects found at Tiryns, indicating that long-distance trade relations resembling trade structures in the palatial period were resumed after the destruction at the end of LH IIIB. Also at Midea, another major Argive LH IIIB settlement, the LH IIIC period sees continuity, for instance, as demonstrated in building activity and finds of pottery (Walberg 1999; Demakopoulou 2007b, 2015; Demakopoulou et al. 2017).

What all of this demonstrates is that activity continues across the divide LH IIIB to LH IIIC. In some important respects, though, it is different. This goes both for Asine and for the Argive region, including the role of Asine in it. The most important indication is the few reported finds of ware of MYBE provenance in the region as a whole; in that sense, the absence in our sample from LH IIIC is true to form. Yet the small size of the sample does not allow for any clear conclusion on this score: the fact that it is not represented in a sample of five sherds does of course not preclude presence as such. Combining this inconclusive observation with the parallel observations that the MYBE pattern seems to disappear from locations further east and that other extra-Argive links can 
be traced in the material at Asine, however, suggests a continuity in the sense that extra-site exchange did not grind to a halt. Rather, exchange networks were either maintained, established anew or developed to fill the gap where others ceased to operate. This happened despite the fate of the palaces, to an extent perhaps also as a result of the collapse. After all, beyond maintaining or re-establishing pre-existing patterns of exchange, it could also include realignment as part of the need or possibilities for filling voids that materialised.

\section{Concluding remarks}

This case study based on a limited number of Late Bronze Age sherds from the settlement of Asine demonstrates the need to include local settlement material in analyses of interaction on regional and inter-regional level. It also shows that Gilstrap's (2014) 'indirect' method could prove fruitful. In addition, such a research strategy will provide us with possibilities of discussing the socio-economic structure in a non-palatial context. As concern the presence of mostly regional pottery from the LH IIIB period, this can be interpreted as for local use (on use, consumption, Jung 2012). This must not be construed as Asine having served as an entrepôt. The type of evidence mustered here does not allow for that. Despite a favourable location that could have implied it serving as a gateway for distribution of high-quality pottery from the Argive region, the demand in Cyprus and the Eastern Mediterranean area falls away as LH IIIB turns LH IIIC (Badre et al. 2005; Jung 2006, 2015, 2018; Mommsen 2011). For now, although evidence of MYBE is locally present in LH IIIC (e.g. at Midea; Demakopoulou et al. 2017), we are compelled to note that extensive export of MYBE seems to have ceased after LH IIIB.

With this in mind, the natural or other calamities that appear to have occurred at the end of LH IIIB was not of such a nature so as to having prevented exchange of widely used products such as ceramic ware of different kinds. Hence, our original question can be answered in the affirmative: albeit of perhaps a slightly different profile, exchange as such does not disappear as Asine moves into LH IIIC. As recent literature suggests for the Argive region as a whole, the recovery was faster and stronger than previously believed, and also the inhabitants of Asine succeeded in maintaining exchange networks either as established earlier or to be replaced by new contacts and sites of production. Thus, while for LH IIIC no ware of the MYBE pattern was represented in our small sample, it appears that Asine was involved in exchange networks of some geographical reach, albeit focused on neighbouring parts of Aegean Greece. This attests to a measure of resilience of the settlement and its place in Argive society. Indeed, combined with the results of excavation at the Lower Town and the reuse of the chamber tombs, we may submit that a measure of affluence was enjoyed also at Asine. All in all, although a small quantity of material only was marshalled for the purposes of this study, we submit that Asine and its hinterland was part of exchange networks in the LH IIIC period, potentially also complex ones that included extra-Argive contact. As such it answers our original question on the resilience of Argive communities beyond the palaces and their continued participation in regional and extraregional exchange.

Acknowledgements We would like to thank the Museum Gustavianum, Uppsala University, and Anne Ingvarsson Sundström curator, for permission to analyse and publish the material from the Asine Collection. A special thanks to professor em. Gullög Nordquist, Uppsala University, for all help and interesting discussions in the archive. We also acknowledge, with gratitude, the staff of the research reactor in Geesthacht for their technical support. We are most grateful to the two anonymous referees for all valuable comments.

Availability of data and material Applicable. Code availability Not applicable.

Author contribution H Mommsen contributed the 'The neutron activation analysis (NAA) procedure and archaeometric results' part in article. B L. Sjöberg contributed in all other parts.

Funding Open access funding provided by University of Gothenburg. We wish to thank the Selma Andersson donation, Uppsala University, for generosity with funding, which made it possible to analyse the material from Asine, stored at the Uppsala University.

\section{Declarations}

Conflict of interest The authors declare no competing interests.

Open Access This article is licensed under a Creative Commons Attribution 4.0 International License, which permits use, sharing, adaptation, distribution and reproduction in any medium or format, as long as you give appropriate credit to the original author(s) and the source, provide a link to the Creative Commons licence, and indicate if changes were made. The images or other third party material in this article are included in the article's Creative Commons licence, unless indicated otherwise in a credit line to the material. If material is not included in the article's Creative Commons licence and your intended use is not permitted by statutory regulation or exceeds the permitted use, you will need to obtain permission directly from the copyright holder. To view a copy of this licence, visit http://creativecommons.org/licenses/by/4.0/.

\section{References}

Åkerström $\AA$ (1987) Berbati 2: the pictorial pottery. ActaAth- $4^{\circ} 36.2$, Svenska Institutet i Athen, Stockholm

Arena E (2015) Mycenaean peripheries during the Palatial Age: the case of Achaia. Hesperia 84:1-46. https://doi.org/10.2972/hesperia.84.1. 0001

Badre L, Boileau MC, Jung R, Mommsen H, Kerschner M (2005) The provenance of Aegean- and Syrian-type pottery found at Tell Kazel (Syria). Ägypten und Levante XV:15-47. https://doi.org/10.1553/ AEundL15s15

Baxter M (2003) Statistics in archaeology. Wiley, London 
Beier T, Mommsen H (1994) Modified Mahalanobis filters for grouping pottery by chemical composition. Archaeometry 36:287-306. https://doi.org/10.1111/j.1475-4754.1994.tb00971.x

Ben-Shlomo D, Maeir AM, Mommsen H (2008) Neutron activation and petrographic analysis of selected Late Bronze and Iron Age pottery from Tell el-Safi/Gath, Israel. J Archaeol Sci 35:956-964. https:// doi.org/10.1016/j.jas.2007.06.020

Crielaard JP (2011) The 'wanax to basileus model' reconsidered: authority and ideology after the collapse of the Mycenaean palaces. In: Mazarakis Ainian A (ed) The "Dark Ages" revisited. Acts of an International Symposium in Memory of William D. E. Coulson, University of Thessaly, Volos, 14-17 June 2007. University of Thessaly Press, Volos, pp 83-111

Deger-Jalkotzy S (2007) Defining LH III C Middle at the cemetery of Elateia-Alonaki in Central Greece. In: Deger-Jalkotzy S, Zavadil M (eds) LH IIIC chronology and synchronism II: LH III C Middle. Proceedings the international workshop held at the Austrian Academy of Sciences at Vienna, October $29^{\text {th }}$ and $30^{\text {th }}, 2004$. Verlag der Österreichischen Akademie der Wissenschaften, Vienna, pp 129-159

Demakopoulou K (2007a) Laconia and Arcadia in LH III C Middle: pottery and other finds. In: Deger-Jalkotzy S, Zavadil M (eds) LH IIIC chronology and synchronism II: LH III C Middle. Proceedings the international workshop held at the Austrian Academy of Sciences at Vienna, October $29^{\text {th }}$ and $30^{\text {th }}, 2004$. Verlag der Österreichischen Akademie der Wissenschaften, Vienna, pp 167174

Demakopoulou K (2007b) The role of Midea in the network of Mycenaean citadels in the Argolid. In: Alram-Stern E, Nightingale G, Bächle AB (eds) Keimelion. Elitenbildung und elitärer Konsum von der mykenischen Palastzeit bis zur homerischen Epoche. Akten des internationalen Kongresses vom 3. bis 5. Februar 2005 in Salzburg. Verlag der Österreichischen Akademie der Wissenschaften, Vienna, pp 65-80

Demakopoulou K (2015) The Mycenaean acropolis of Midea. In: Scahllin AL, Tournavitou I (eds) Mycenaeans up to date: the archaeology of the north-eastern Peloponnese - current concepts and new directions. ActaAth- $4^{\circ}$ 56, Svenska Institutet i Athen, Stockholm, pp 185-196

Demakopoulou K, Divari-Valakou N, Maran J, Mommsen H, Prillwitz S, Walberg G (2017) Clay paste characterization and provenance determination of Middle and Late Helladic vessels from Midea. Opuscula 10:7-49. https://doi.org/10.30549/opathrom-10-02

Drake BL (2012) The influence of climatic change on the Late Bronze Age collapse and the Greek Dark Ages. J Archaeol Sci 39:1862 1870. https://doi.org/10.1016/j.jas.2012.01.029

Drews R (1993) The end of the Bronze Age: changes in warfare and the catastrophe ca. 1200 BC. Princeton University Press, Princeton, NJ

Driessen J (ed) (2018) An archaeology of forced migration: crisis-induced mobility and the collapse of the $13^{\text {th }} \mathrm{c}$. BCE Eastern Mediterranean. Presses universitaires de Louvain, Louvain-la Neuve

Finné M, Holmgren K, Shen CC, Hu HM, Boyd M, Stocker S (2017) Late Bronze Age climate change and the destruction of the Mycenaean Palace of Nestor at Pylos. PLoS One 12(12): e0189447. https://doi.org/10.1371/journal.pone.0189447

Forsén J, Mommsen H, Shriner C (2017) Some preliminary remarks concerning a neutron activation analysis (NAA) study and fabric correlation of ceramic samples from Asea in Arcadia, Greece. In: Soueref K, Kotzabopoulou E, Liampi K, Morris SP, Papadopoulos

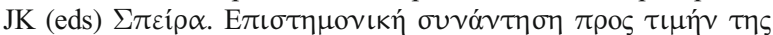

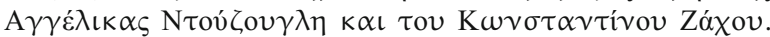
Ekdoseis Mermenka, Athens, pp 91-108

French EB, Stockhammer PH (2009) Mycenae and Tiryns: the pottery of the second half of the thirteenth century $\mathrm{BC}$ - context and definitions. Annu Br Sch at Athens 104:175-232. https://doi.org/10.1017/ S006824540000023X
Frizell B (1978) Finds of the Late Helladic period. In: Hägg I, Hägg R (eds) Excavations in the Barbouna Area at Asine. Boreas 4(2): 6391

Frödin O, Persson AW (1938) Asine [I]. Results of the Swedish excavations 1922-1930. Generalstabens Litografiska Anstalts Förlag, Stockholm

Furumark A (1941) The Mycenaean pottery: analysis and classification. Wahlström \& Widstrand, Stockholm

Galaty ML (1999) Nestor's wine cups: investigating ceramic manufacture and exchange in a Late Bronze Age 'Mycenean' state. BAR 766, British Archaeological Reports, Oxford

Galaty ML, Parkinson WA (eds) (2007) Rethinking Mycenaean palaces II. Revised and expanded second edition, Monograph 60, Cotsen Institute of Archaeology Press, Los Angeles, CA. https://doi.org/ 10.2307/j.ctvdjrrnk

Gauss W, Kiriatzi E, Lindblom M, Lis B, Morrison JE (2017) Aeginetan Late Bronze and Early Iron Age cooking pottery. In: Hruby J, Trusty DA (eds) From cooking vessels to cultural practices in the Late Bronze Age Aegean. Oxbow, Oxford, pp 46-56

Gilboa A, Shalev Y, Lehmann G, Mommsen H, Erickson B, Nodarou E, Ben-Shlomo D (2017) Cretan pottery in the Levant in the fifth and fourth centuries BCE and its historical implications. Am J Archaeol 121:559-593. https://doi.org/10.3764/aja.121.4.0559

Gilstrap W (2014) Indirect evidence for pottery production on the island of Aegina during the transitional LH IIIB-LH IIIC Early period. In: Kassianidou V, Dikomitou-Eliadou M (eds) The Narnia Project: integrating approaches to ancient material culture. NARNIA Project and the Archaeological Research Unit, University of Cyprus, Nicosia, pp 8-41

Gilstrap W (2016) Pottery production at two neighbouring centres in the Late Bronze Age Saronic Gulf: historical contingency and craft organisation. J Archaeol Sci Rep 7:499-509. https://doi.org/10. 1016/j.jasrep.2016.03.004

Gunnewee J, Michel VH (1999) Does the different layout of the Late Bronze Age tombs at Laish/Dan and Akko in the northern Canaan reflect different trade relations? An instrumental Neutron Activation Study on Mycenaean pottery. J Archaeol Sci 26:989-995. https:// doi.org/10.1006/jasc. 1999.0420

Halstead P (1992) The Mycenaean palatial economy: making the most of the gaps in the evidence. Proc Camb Philol Soc 38:57-86. https:// doi.org/10.1017/S0068673500001620

Huy, S., Mommsen, H., Dally, O., (2020/2) Herkunftsbestimmung von Keramik aus der Siedlung Taganrog am unteren Don durch Neutronenaktivierungsanalyse, Archäologischer Anzeiger. DAI.publications: https://doi.org/10.34780/aa.v0i2.1030

Jung R (2006) Die mykenische Keramik von Tell Kazel (Syrien). Damaszener Mitteilungen 15:147-218

Jung R (2012) Can we say, what's behind all those sherds? Ceramic innovations in the Eastern Mediterranean at the end of the second millennium. In: Maran J, Stockhammer PW (eds) Materiality and social practice: transformative capacities of intercultural encounters. Oxbow, Oxford, pp 104-120

Jung R (2015) Imported Mycenaean pottery in the East: distribution, context and interpretation. In: Eder B, Pruzsinszky R (eds) Policies of exchange: political systems and mode of interaction in the Aegean and Near East in the $2^{\text {nd }}$ millennium BCE. Austrian Academy of Science Press, Vienna, pp 243-275

Jung R (2018) Mycenaean pottery in coastal Syria. In: Badre L. Capet E, Vitale B (eds) Tell Kazel au Bronze Récent. Études céramiques. Bibliothèque archéologique et historique 211, Institut français du Proche-Orient, Beirut, pp 47-51, Plates XLV-XVLIII

Jung R, Mommsen H, Pacciarelli M (2015) From west to west: determining production regions of Mycenaean pottery of Punta di Zambrone (Calabria, Italy). J Archaeol Sci Rep 3:456-463. https://doi.org/10. 1016/j.jasrep.2015.07.004 
Karageorghis V, Asaro F, Perlman I (1972) Concerning two Mycenaean pictorial sherds from Kouklia (Palaepaphos), Cyprus. Archäologischer Anzeiger:188-197

Kardamaki E, Day PM, Tenconi M, Maran J, Papadimitrou A (2016) Transport stirrup jars in Late Mycenaean Tiryns: maritime containers and commodity movement in political context. In: Demesticha S, Knapp AB (eds) Maritime transport containers in the Bronze-Iron Age Aegean and Eastern Mediterranean. Åströms Förlag, Uppsala, pp 145-167

Karkanas P, Berna F, Fallu D, Gau $\beta$ W (2019) Microstratigraphic and mineralogical study of a Late Bronze Age updraft pottery kiln, Kolonna site, Aegina Island, Greece. Archaeol Anthropol Sci 11: 5763-5780. https://doi.org/10.1007/s12520-019-00903-7

Kilian K (1981) Ausgrabungen in Tiryns, 1978, 1979. Archäologischer Anzeiger:149-193

Kilian K (1982) Ausgrabungen in Tiryns, 1980. Archäologischer Anzeiger:383-439

Klintberg L (2011) The Late Helladic period. In: Lindblom M, Wells B (eds) Mastos in the Berbati Valley: an intensive archaeological survey. ActaAth-4 54, Svenska Institutet i Athen, Stockholm, pp 97118

Knapp AB, Manning SW (2016) Crisis in context: the end of the Late Bronze Age in the eastern Mediterranean. Am J Archaeol 120:99 149. https://doi.org/10.3764/aja.120.1.0099

Knappett C (2001) Overseen or overlooked? Ceramic production in a Mycenaean palatial system. In: Voutsaki S, Killen J (eds) Economy and politics in the Mycenaean palace states. Cambridge Philological Society, Cambridge, pp 80-95

Lantzas K (2016) Reconsidering collapse: identity, ideology, and postcollapse settlement in the Argolid. In: Faulseit RK (ed) Beyond collapse: archaeological perspectives on resilience, revitalization, and transformation in complex societies. Center for Archaeological Investigations Occasional Paper 42, Southern Illinois University Press, Carbondale, IL, pp 459-485

Lindblom M, Nordquist G, Mommsen H (2018) Two Early Helladic II terracotta rollers from Asine and their glyptic context. Opuscula 11: 81-96. https://doi.org/10.30549/opathrom-11-04

Lis B, Mommsen H, Maran J, Prillwitz S (2020) Investigating pottery production and consumption patterns at the Late Mycenaean cemetery of Perati. J Archaeol Sci Rep 32:102453. https://doi.org/10. 1016/j.jasrep.2020.102453

Maran J (2002-2003) The town of Tiryns after the fall of the palace: some new insight. Bull Inst Class Stud 46:223-224

Maran J (2005) Late Minoan coarse ware stirrup jars on the Greek Mainland: a postpalatial perspective from the $12^{\text {th }}$ century BC Argolid. In: D'Agata AL, Moody J (eds) Ariadne's threads: connections between Crete and the Greek Mainland in Late Minoan III (LM IIIA2 to LM IIIC). Proceedings of the International Workshop held at Athens, Scuola Archeologica Italiana, 5-6 April 2003. Scuola Archeologica Italiana, Athens, pp 415-431

Maran J (2006) Coming to terms with the past: ideology and power in Late Helladic IIIC. In: Deger-Jalkotzy S, Lemos IS (eds) Ancient Greece: from the Mycenaean palaces to the Age of Homer. Edinburg University Press, Edinburgh, pp 123-150

Maran J (2009) The crisis years? Reflections on signs of instability in the last decades of the Mycenaean palaces. Scienze dell Antichità: Storia Archeologia Antropologia 15:241-262

Maran J (2015) Tiryns and the Argolid in Mycenaean times. In: Scahllin AL, Tournavitou I (eds) Mycenaeans up to date: the archaeology of the north-eastern Peloponnese - current concepts and new directions. ActaAth $-4^{\circ} 56$, Svenska Institutet i Athen, Stockholm, pp 277-292

Maran J, Papadimitriou A (2006) Forschungen im Stadtgebiet von Tiryns 1999-2002. Archäologischer Anzeiger 1:97-169

Maran J, Papadimitriou A (2016) Gegen den Strom der Geschichte. Die nördliche Unterstadt von Tiryns: ein gescheitertes
Urbanisierungsprojekt der mykenischen Nachpalastzeit. Archäologischer Anzeiger 2:19-118

Middleton GD (2012) Nothing lasts forever: environmental discourses on the collapse of past societies. J Archaeol Res 20:257-307. https:// doi.org/10.1007/s10814-011-9054-1

Mommsen H (2011) Provenancing of pottery. In: Nuclear techniques for cultural heritage research. International Atomic Energy Agency, Vienna, pp 41-70

Mommsen H (2012) The importance of a reliable grouping - neutron activation analysis (NAA) data of Mycenaean pottery sherds reevaluated with the Bonn filter method. J Archaeol Sci 39:704-707

Mommsen H, Maran J (2000-2001) Production places of some Mycenaean pictorial vessels: the contribution of chemical analysis. Opuscula Atheniensia 25-26:95-106

Mommsen H, Sjöberg BL (2007) The importance of the 'best relative fit factor' when evaluating elemental concentration data of pottery demonstrated with Mycenaean sherds from Sinda, Cyprus. Archaeometry 48:359-371. https://doi.org/10.1111/j.1475-4754. 2007.00306.x

Mommsen H, Kreuser A, Weber J (1988a) A method for grouping pottery by chemical composition. Archaeometry 30:47-57. https://doi.org/ 10.1111/j.1475-4754.1988.tb00434.x

Mommsen H, Lewandowski E, Weber J, Podzuweit CH (1988b) Neutron activation analysis of Mycenaean pottery from the Argolid: the search for reference groups. In: Farquhar M, Hancock RGV, Pavlish LA (eds) Proceedings of the 26th International Archaeometry Symposium. Toronto, ONT, pp 165-171

Mommsen H, Kreuser A, Lewandowski E, Weber J (1991) Provenancing of pottery: a status report on neutron activation analysis and classification. In: Hughes M, Cowell M, Hook D (eds) Neutron activation and plasma emission spectrometric analysis in archaeology. Occasional Papers 82, British Museum, London, pp 57-65

Mommsen H, Gauß W, Hiller S, Ittameier D, Maran J (2001) Charakterisierung bronzezeitlicher Keramik von Ägina durch Neutronenaktivierungsanalyse. In: Pohl E, Recker U, Theuner C (eds) Archäologisches Zellenwerk. Beiträge zur Kulturgeschichte in Europa und Asien. Festschrift Helmut Roth zum 60. Geburtstag. Internationale Archäologie, Studia Honoraria 16, Verlag Marie Leidorf, Rahden/Westfalen, pp 79-89

Mommsen H, Mountjoy P, Özyar A (2011) Provenance determination of Mycenaean IIIC vessels from the 1934-1939 excavations at TarsusGözlükule by neutron activation analysis. Archaeometry 54:900 915. https://doi.org/10.1111/j.1475-4754.2010.00583.x

Mommsen H, Bentz M, Boix A (2016) Provenance of red-figured pottery of the classical period excavated at Olympia. Archaeometry 58:371379. https://doi.org/10.1111/arcm.12180

Mountjoy PA (1986) Mycenaean decorated pottery: A guide to identification. Studies in Mediterranean archaeology 73. Paul Åström förlag. Göteborg

Mountjoy PA (1996) Asine chamber tomb I:1: the potter. In: Hägg R, Nordquist G, Wells B (eds) Asine III. Supplementary studies on the Swedish excavations 1922-1930. ActaAth-4 45:1, Svenska Institutet i Athen, Stockholm, pp 47-67

Mountjoy PA, Mommsen H (2001) Mycenaean pottery from QantirPiramesse, Egypt. Annu Br Sch at Athens 96:123-155. https://doi. org/10.1017/S0068245400005244

Mühlenbruch T (2007) The post-palatial settlement in the Lower Citadel of Tiryns. In: Deger-Jalkotzy S, Zavadil M (eds) LH IIIC chronology and synchronism II: LH III C Middle. Proceedings the International Workshop held at the Austrian Academy of Sciences at Vienna, October $29^{\text {th }}$ and $30^{\text {th }}, 2004$. Verlag der Österreichischen Akademie der Wissenschaften, Vienna, pp 243-251

Mühlenbruch T, Mommsen H (2011) Neutronenaktivierungsanalysen an mykenischer Keramik aus Kusakli-Sarissa und Sirkeli (Türkei), Kamid el-Loz-Kumidi (Libanon) und dem Fayum (Ägypten), Ägypten und Levante XXI:281-290 
Nakassis D, Parkinson WA, Galaty ML (2011) Redistribution in Aegean palatial societies. Redistributive economies from a theoretical and cross-cultural perspective. Am J Archaeol 15:177-184. https://doi. org/10.3764/aja.115.2.0177

Nordquist G, Hägg R (1996) The history of the Asine excavations and collections, with a biography. In: Hägg R, Nordquist G, Wells B (eds) Asine III. Supplementary studies on the Swedish excavations 1922-1930. ActaAth-4 45:1, Svenska Institutet i Athen, Stockholm, pp 11-18

Nordquist G, Lindblom M (2020) Curating the past: Asine and PRAGMATA. In: Mæhle IB, Ravnå PB, Seland EH (eds) Methods and models in ancient history: essays in honor of Jørgen Christian Meyer. Papers and Monographs from the Norwegian Institute at Athens 9, Athens, pp 285-294

Nur A, Cline EH (2000) Poseidon's horses: plate tectonics and earthquake storms in the Late Bronze Age Aegean and Eastern Mediterranean. J Archaeol Sci 27:43-63. https://doi.org/10.1006/ jasc. 1999.0431

Parkinson MA, Nakassis D, Galaty ML (2013) Crafts, specialist, and markets in Mycenaean Greece. Introduction. Am J Archaeol 117: 413-422. https://doi.org/10.3764/aja.117.3.0413

Penttinen A (1996) Excavations on the Acropolis of Asine 1990. Opuscula Atheniensia 21:149-167

Perlman A, Asaro F (1969) Pottery analyses by neutron activation. Archaeometry 11:21-52. https://doi.org/10.1111/j.1475-4754. 1969.tb00627.x

Pullen DJ (2013) Crafts, specialists, and markets in Mycenaean Greece. Exchanging the Mycenaean economy. Am J Archaeol 117:437445. https://doi.org/10.3764/aja.117.3.0437

Rahmtorf L (2015) Workshop activities and pyrotechnology at Mycenaean Tiryns. In: Scahllin AL, Tournavitou I (eds) Mycenaeans up to date: the archaeology of the north-eastern Peloponnese - current concepts and new directions. ActaAth- $4^{\circ}$ 56, Svenska Institutet i Athen, Stockholm, pp 143-149

Santillo Frizell B (1980) An early Mycenaean settlement at Asine: the Late Helladic IIB-III A:1 pottery. Dissertation, University of Gothenburg, Gothenburg

Santillo Frizell B (1986) Asine II. Results of the excavations east of the Acropolis 1970-1974, Fasc. 3: the Late and final Mycenaean periods. ActaAth- $4^{\circ}$ 24:3, Svenska Institutet i Athen, Stockholm

Schallin AL (1997) The Late Bronze Age potter's workshop at Mastos in the Berbati Valley. In: Gillis C, Risberg C, Sjöberg B (eds) Trade and production in premonetary Greece: production and the craftsman. Proceedings of the 4th and 5th International Workshops, Athens 1994 and 1995. Paul Åströms Förlag, Jonsered, pp 73-88

Schallin AL (2015) Mycenaean figures and figurines from the Potter's Workshop at Mastos in the Berbati Valley. In: Scahllin AL, Tournavitou I (eds) Mycenaeans up to date: the archaeology of the north-eastern Peloponnese - current concepts and new directions. ActaAth- $4^{\circ}$ 56, Svenska Institutet i Athen, Stockholm, pp 197-209

Schwedt A, Aravantinos V, Harami A, Kilikoglou V, Kylafi M, Mommsen H, Zacharias N (2006) Neutron activation analysis of Hellenistic pottery from Boeotia, Greece. J Archaeol Sci 33:10651074. https://doi.org/10.1016/j.jas.2005.11.009

Shelmerdine CW (2013) Crafts, specialists, and markets in Mycenaean Greece. Economic interplay among households and states. Am J Archaeol 117:447-452. https://doi.org/10.3764/aja.117.3.0447

Sjöberg BL (1996) Five Mycenaean vases from Zafer Aga, 1924. In: Hägg R, Nordquist G, Wells B (eds) Asine III. Supplementary studies on the Swedish excavations 1922-1930. ActaAth-4 $45: 1$, Svenska Institutet i Athen, Stockholm, pp 101-110
Sjöberg BL (1997) Two possible Late Helladic kilns at Asine: a research note. In: Gillis C, Risberg C, Sjöberg B (eds) Trade and production in premonetary Greece: production and the craftsman. Proceedings of the 4th and 5th International Workshops, Athens 1994 and 1995. Paul Åströms Förlag, Jonsered, pp 89-100

Sjöberg BL (2004) Asine and the Argolid in the Late Helladic III period: a socio-economic study. BAR International Series 1225 , Archaeopress, Oxford

Small DB (1998) Surviving the collapse: the oikos and structural continuity between the Late Bronze Age and later Greece. In: Gitin S, Mazar A, Stern E (eds) Mediterranean peoples in transition: thirteenth to early tenth centuries BCE. In honor of Professor Trude Dothan. Israel Exploration Society, Jerusalem, pp 283-291

Spataro M, Garnett A, Shapland A, Spencer N, Mommsen H (2019) Mycenaean pottery from Amara West (Nubia, Sudan). Archaeol Anthropol Sci 11:683-697. https://doi.org/10.1007/s12520-0170552-z

Stockhammer P (2009) The change of pottery's social meaning at the end of the Bronze Age: new evidence from Tiryns. In: Bachhuber C, Roberts RG (eds) Forces of transformation: the end of the Bronze Age in the Mediterranean. BANEA Monograph Series 1, Oxbow, Oxford, pp 164-169

Stockhammer P (2011) Household archaeology in LHIIIC Tiryns. In: Yasur-Landau A, Ebeling JR, Mazow LB (eds) Household archaeology in ancient Israel and beyond. Culture and History of the Ancient Near East 50, Brill, Leiden, pp 207-236

Walberg G (1999) The end of the Late Bronze Age at Midea. In: Laffineur R (ed) Polemos. Le contexte guerrier en Égée à l'âge du bronze. Aegaeum 19:157-160

Weiberg E, Finné M (2018) Resilience and persistence of ancient societies in the face of climate change: a case study from Late Bronze Age Peloponnese. World Archaeol 50:584-602. https://doi.org/10.1080/ 00438243.2018.1515035

Weiberg E, Lindblom M, Sjöberg BL, Nordquist, G (2010) Social and environmental dynamics in Bronze and Iron Age Greece. In: Sinclair PJJ, Nordquist G, Herschend F, Isendahl C (eds) The urban mind: cultural and environmental dynamics. Studies in Global Archaeology 15, Department of Archaeology and Ancient History, Uppsala University, Uppsala, pp 149-194

Whitelaw T (2001) Reading between the tablets: assessing Mycenaean palatial involvement in ceramic production. In: Voutsaki S, Killen J (eds) Economy and politics in the Mycenaean palace states. Cambridge Philological Society, Cambridge, pp 51-79

Whittaker H (2017) The Sea Peoples and the collapse of Mycenaean palatial rule. In: Fischer PM, Bürge T (eds) "Sea Peoples" up-todate: new research on transformation in the Eastern Mediterranean in the 13th-11th centuries BCE. Verlag der Österreichischen Akademie der Wissenschaften, Vienna, pp 75-81

Zangger E (1991) Prehistoric coastal environments in Greece: the vanished landscapes of Dimini Bay and Lake Lerna. J Field Archaeol 18:1-15. https://doi.org/10.1179/009346991791548799

Zangger E (1994) Landscape changes around Tiryns during the Bronze Age. Am J Archaeol 98:189-212. https://doi.org/10.2307/506635

Zuckerman A, Ben-Schlomo D, Mountjoy PA, Mommsen H (2010) A provenance study of Mycenaean pottery from Northern Israel. J Archaeol Sci 37:409-416. https://doi.org/10.1016/j.jas.2009.10.005

Publisher's note Springer Nature remains neutral with regard to jurisdictional claims in published maps and institutional affiliations. 